\title{
Issues in the Economics of Industrialization in Developing Countries: A Case Study from Pakistan's Light Engineering Sector
}

\author{
IJAZ NABI*
}

\section{INTRODUCTION}

Some of the factors which determine the efficient use of scarce resources in industrial development are: the size of firms in the industry [1;10 and 22], the type of technology - 'sophisticated' or 'traditional' - used in the production process [9;18;19 and 21] , availability of skilled manpower [7], depth of the entrepreneurial talent [2; 6 and 15], and judicious policies regarding industrial location [20] . In the discussion that follows we attempt to quantify the impact of these factors on firm efficiency, using evidence from Pakistan.

The issues are examined with detailed data collected in 1982-83 in three rounds of surveys of 120 firms manufacturing agricultural machinery in Pakistan. (The survey is described in detail in [11].) This sample constitutes 23 percent of the total population of 514 firms in the industry identified in a census conducted by the Agricultural Machinery Division of the Pakistan Agricultural Research Council in $1983[13 ; 14]$.

The paper is structured as follows. An overview of the agricultural machinery industry in Pakistan is presented in Section 2. The statistical procedure and the results are discussed in Section 3. Finally, concluding remarks are made in Section 4.

\section{PAKISTAN'S AGRICULTURAL IMPLEMENTS INDUSTRY; AN OVERVIEW}

The introduction of new dwarf wheat and rice varieties and chemical fertilizers in the 1960s resulted in an impressive growth of Pakistan's agriculture. ${ }^{1}$ The sector grew at a rate between 3 percent and 6 percent per annum peaking at 15 percent in

*Assistant Professor, Department of Economics, Quaid-i-Azam University, Islamabad. Funds for the study were provided by the International Development Research Centre, Ottawa, Canada.

${ }^{1}$ From 1966 to 1969 wheat and rice production in West Pakistan increased by 79 percent and 61 percent respectively [17]. 
the late Sixties. This growth generated considerable demand for agricultural machinery, in particular, machinery for irrigation such as tubewell engines and water pumps which ensured timely supplies of water and thus facilitated the use of chemical fertilizers. This was also a period when mechanization of other farm activities, such as ploughing and threshing, also started. By the late 1970s farmers had started complaining of shortages of labour at peak periods of sowing and harvesting. ${ }^{2}$ The result was a rapid increase in the use of tractors and tractor-driven threshers. The latter may have contributed significantly to increased cropping intensity by enabling timely harvest of wheat for sowing cotton in southern Punjab and rice in central Punjab. Agronomists have termed this phenomenon "thresher revolution", following the earlier "green revolution". Demand was also created for other machinery such as trolleys for marketing the increased agricultural produce. The modern agricultural implements industry in Pakistan came to exist in response to this demand by the agricultural sector.

\section{The Industry's Structure}

The five broad categories of implements manufactured in the industry are tubewell machinery, threshers, trolleys, tractor attachments (such as fertilizer- and seed-drills and various categories of ploughs) and sugarcane crushers and fodder cutters. We have defined small firms as those which employ less than 10 workers. This definition corresponds to the one used by the Government of Pakistan for firms that use power. (All the firms in our sample use power.) Our sample of firms shows that 34 percent of the firms in the industry are large and they control 65 percent of the industry's assets. An important feature of the industry is its concentration in a few towns in the Punjab. These towns are Daska, Sialkot, Gujranwala, Faisalabad, Multan, Lahore and Mian Channun [16]. The modal stated reasons by entrepreneurs for this concentration are concentration of manufacturing skills (as in Daska), concentration of manufacturers who migrated from agricultural machinery manufacturing centres in Batala, India (as in Faisalabad and Mian Channun), access to raw material (as in Faisalabad and Lahore), and access to specialized markets for the machinery (as in Mian Channun, Gujranwala/Sialkot and Daska). A breakdown of firms by product groups and location is given in Table 1.

\section{The Technology}

The production process in the industry provides a good example of adaptation of imported technology to local needs. For example, tubewell engines being manufactured in the industry are slowly evolving versions of the original and technologically simple single-piston 'Rustin' engine designed in England in the 1920s. The

${ }^{2}$ Around this time, labour migration from Pakistan to the oil-rich Middle East increased sharply. This may have contributed to the shortage of labour directly and also indirectly by raising the reserve wage rate.
Table 1

Breakdown of Firms by Product Groups and Location

\begin{tabular}{|c|c|c|c|c|c|c|c|}
\hline \multirow[b]{2}{*}{ City/Town } & \multicolumn{5}{|c|}{ Number of Sample Firms Producing } & \multirow{2}{*}{$\begin{array}{c}\text { Total } \\
\text { Number } \\
\text { of } \\
\text { Sample } \\
\text { Firms }\end{array}$} & \multirow{2}{*}{$\begin{array}{l}\text { Sample Firms } \\
\text { as Percentage } \\
\text { of Total } \\
\text { Sample } \\
\text { (119) }\end{array}$} \\
\hline & Tubewells & Threshers & Trolleys & $\begin{array}{l}\text { Tractor } \\
\text { attach- } \\
\text { ments }\end{array}$ & $\begin{array}{l}\text { Sugar- } \\
\text { cane \& } \\
\text { chaff- } \\
\text { cutters }\end{array}$ & & \\
\hline Daska & 16 & 2 & - & 3 & - & 21 & 17.7 \\
\hline Sialkot/Gujranwala & $\mathrm{a}-$ & 12 & 4 & 4 & - & 20 & 16.8 \\
\hline Faisalabad & - & 2 & - & - & 18 & 20 & 16.8 \\
\hline Multan & 1 & 12 & 5 & 2 & - & 20 & 16.8 \\
\hline Lahore & 8 & - & 5 & 5 & - & 18 & 15.1 \\
\hline Mian Channun & - & 18 & - & 2 & - & 20 & 16.8 \\
\hline Total & 25 & 46 & 14 & 16 & 18 & 119 & 100.0 \\
\hline $\begin{array}{l}\text { No. of Firms as } \\
\text { Percentage of } \\
\text { Total Sample (119) }\end{array}$ & 21 & 38.7 & - Percentage & 13.4 & 15.1 & & \\
\hline
\end{tabular}

thresher is a slightly improved version of the Indian design of the early 1960s. None of the firms we visited used technical drawings or, indeed, had workers who could read them. Typically, the manufacturer himself had acquired the engineering skill in some other firm before starting his own. He makes the prototype which is copied by his workers. Some experimentation does take place, in particular, regarding thresher design to suit local needs and to compete through product differentiation. Usually this amounts to varying the number of beaters in the drum which affects the yield or by altering the feeding system so that fewer men are needed to operate the thresh er. These, however, are minor variations requiring little engineering skills.

There is a clear pattern in the machinery used in the industry. Tubewell engines, fodder cutters and sugarcane crushers are made up of parts which are cast in the small foundries located on the premises of the firms and managed by skilled ironsmiths. The rough castings require considerable machining with planers and various shaping machines so that they can be fitted together. For threshers, on the other hand, metal-cutting machines and welding plants are more important. Firms manufacturing various tractor attachments, such as trolleys, purchase most of the required parts in the wholesale markets of Lahore and Faisalabad. Few operations 
and skills are needed for putting them together to manufacture the finished product Welding plants and simple hand-operated tools are enough to undertake production. ${ }^{3}$ What is striking about the machinery, however, is that nearly all of it is locally made; some firms even make their own. Planning, honing and milling machines (the las two are used for precision work and thus involve sophisticated technology) are the only machines which are imported on any important scale. Significantly, entrepreneurs were quite satisfied with the engineering performance of the locally manufactured machinery.

\section{The Raw Material}

The raw material used in the industry consists primarily of pig iron, steels of various strengths in the form of mild steel plates, angle iron and rods, ball bearings and nuts and bolts. Pig iron is used for casting parts and it is important for firms manufacturing tubewell machinery, fodder cutters and sugar-cane crushers. It is combined in various proportions, depending on the part to be cast, with scrap purchased from the ship-breaking industry in Karachi. Until recently, pig iron was imported in large quantities. With the commissioning of the Pakistan Steel Mill, however, reliance on imports has decreased. Most of the entrepreneurs were quite enthusiastic about the quality of pig iron produced by the Mill and described it as 'soft' and easy to machine.

We did not observe any special problems regarding availability of raw material in the industry. Most items are locally available in the towns where firms are located, although Lahore is the main market. There is no restriction on the minimum quantities purchased. Various arrangements regarding payment exist depending on the relationship between the entrepreneurs and the sellers. The usual practice is to pay up to half the price at the time of purchase and the remaining half within a period of up to one month. As we shall see in our discussion on capital markets, this arrangement is important, given that supplies of working capital are inadequate.

\section{The Capital Market}

The industry faces a highly segmented capital market. We may distinguish between formal and informal sources of finance. In the former are included commercial banks and specialized credit institutions such as the Industrial Development Bank of Pakistan (IDBP). These institutions provide long-term loans and the specialized credit institutions also lend at low interest rates. They use elaborate procedures involving detailed criteria for determining the suitability of potential

${ }^{3}$ The main difference between small and large firms regarding the production process lies in the number of operations subcontracted to other firms. Small firms producing tubewells usually do not do their own casting. Similarly, small firms manufacturing tractor parts purchase their parts cut to order and thus do not require heavy cutting machines. borrowers which results in only a small proportion $(27 \%)$ of the firms in the farm machinery industry borrowing from these institutions. In another paper [12] , we have attempted to identify firm characteristics that increase the probability of borrowing from these institutions. We find that being located in a small town increases the firm's chances of borrowing in formal capital markets, perhaps because in such towns there is little competition for loanable funds from other enterprises. Firms manufacturing items in high and growing demand, such as threshers, have a higher probability of borrowing than other firms. The size of the firm, measured in terms of its fixed assets, is also important. In addition to these, the backgrounds of firm owners also matter. Educated entrepreneurs are more likely to succeed in borrowing than the uneducated entrepreneurs. Technical education of the entrepreneur, in particular, fetches a high premium and appears to facilitate borrowing significantly.

Most of the funds in the industry are raised in the informal capital markets (as was the case in 1970 when Child \& Kaneda studied the industry [13]). Here we include sources of finance such as friends and relatives (particularly those who have migrated to the Middle East), the back-street operators and the increasingly popular 'committee system'. The last involves formation of committees of members belonging to the same biradari (a 'brotherhood' based on such shared traits as caste, vocation, origin, etc.) as a check against default, and pooling monthly instalments for which lots are drawn. The person who is first in the queue may 'sell' his turn to another. Our estimate is that the real interest rate resulting from such purchases varies between 25 percent and 40 percent. The total amounts involved are between Rs. 100,000 and Rs. $15,00,000$ and a committee may last up to 40 months. Funds thus raised are used mainly as working capital. Other sources of working capital are consumer advances and wholeseller's raw material advances.

We find that firms that have access to the formal capital markets have capital stocks which, on average, are 3 to 4 times as large as those of the other firms. The growth rate of capital stock in these firms is also considerably higher. Regarding future prospects of borrowing, these firms expect to finance nearly half of their intended investments for 1983-84 (a total of Rs. 3,926,000) through borrowing in the formal capital markets.

\section{The Entrepreneurial Profile}

Twenty-one percent of the entrepreneurs in our sample are those who are generally known as 'refugees', i.e. those who migrated to Pakistan from Batala (India) in 1947. It is this concentration which has resulted in the widespread belief that the industry is dominated by 'refugees'. Also, the largest firms, in terms of both the number of workers employed and the size of capital stock, are owned by 
'refugees . Numbering 71, which is 60 percent of the total, the entrepreneurs overwhelmingly belong to the lohar ${ }^{4}$ biradari (i.e. the ironsmith community). Other important biradaris (communities) in the industry are Rajputs (10), Arains (9) and Sheikhs (5). Of these, the first two are agriculturists but sheikhs are considered to be sharp businessmen. Only 5 entrepreneurs are non-Punjabis, 2 being Baluch and 3 Pathans. Thirty-seven entrepreneurs ( 31 percent of the entrepreneurs in our sample) have had no formal schooling at all, 32 of them ( 51 percent of the sample) have had schooling up to matriculation, 13 (i.e. 11 percent of the sample) have had college education up to intermediate level and seven of them ( $=6$ percent of the sample) have university degrees. Only six entrepreneurs reported having technical education.

Although most (112 out of 119) of the firms we visited had been in the industry for less than 10 years, the entrepreneurs running those firms have had a long experience of working in related industries. Typically, they were skilled workers manufacturing simple agricultural implements (such as ploughs, scythes, etc.) prior to entering the industry. Some were also involved in wholesale and retail trade of agricultural implements. Only nine entrepreneurs are agriculturists-turnedindustrialists. Only seven entrepreneurs reported immediate relatives who had migrated to the Middle-East and were sending back remittances for investment in the industry. However, most entrepreneurs who borrow in the informal-sector capital markets believe that migrants' remittances are an important source of cash flows in these markets. To sum up, the most distinguishing feature of the entrepreneurs in the industry is that they belong to the lohar biradari which, throughout the history of this region, has been entrusted with the task of manufacturing agricultural implements.

\section{The Labour Market}

Altogether 1360 workers are employed in the industry. Broadly speaking, there are eight skill categories: turners, welders, fitters, shapermen, painters, helpers, apprentices and foremen. (Nearly 66 percent of the workforce falls in these skill categories.) The wages range between Rs. 170 for apprentices and Rs. 807 for fitters. Most workers are young (below 25 years) and literate (nearly 82 percent can read and write). There are very few instances where workers are related to owners of the firms in which they are employed.

Workers, on average, commute $2-3$ miles to work and are drawn largely from the lohar biradari residing in nearby villages and engaged in manufacturing and repairing simple agricultural implements. With mechanization, the availability of such job opportunities nearby means that traditional ironsmiths are being trained

${ }^{4}$ Lohars (ironsmiths) like to call themselves 'mughals' tracing their origin to the ironsmiths who accompanied the Mughal forces, making arms during the campaigns. to look after the new, more sophisticated, farm machinery. The capital-intensive firms tend to employ a greater proportion of skilled workers, semi-skilled workers and apprentices than are employed by other firms. There is a high turnover rate of foremen in the industry.

Our analysis of the factors segmenting the labour market (see [4]) suggests that within each skill category there is a considerable variation in workers' earnings. There is an inverse U-shaped relationship between workers' experience and their earnings. Workers employed by large firms have, on average, higher earnings. Belonging to the lohar biradari also helps in getting higher wages for most categories of skills. Further, firms in small towns pay lower wages to their workers than firms in large cities. Education does not appear to be related to workers' earnings.

Regarding workers' mobility, it appears that most workers are content with where they are living and have no desire to move to another town. They would, however, like to move to a bigger factory in the same town, preferably one which manufactures farm machinery. Forty-three percent of the workers would like to seek jobs overseas, mostly in Saudi Arabia. Although many workers have relatives abroad, most feel that their relatives will not help them in getting employment. Very few workers want to change their skills. Half the workers we interviewed said that if they had access to capital, they would like to set up their own firm.

\section{THE STATISTICAL PROCEDURE AND THE RESULTS}

There are differences in firms regarding the technology used within the agricultural machinery sector. It seemed inappropriate to fit production and profit functions that do not take into account such differences. We therefore used statistical procedures to determine firm groups. We first specified a Cobb-Douglas production function and estimated the residual sum of squares for different firm groups. We then performed F-tests to identify firm groups that are statistically similar regarding production techniques. The firm groups finally identified were small firms ( $\leqslant 10$ workers), large firms ( $>10$ workers), tubewell firms and nontubewell firms.

To comment on returns to scale and technical efficiency we, following Lau and Yotopoulos [8] and Yotopoulos [23], used procedures whereby a simultaneous system of equations consisting of the production function, the profit function and labour demand functions are estimated, with the help of Zellner's efficient estimation procedure [24]. The estimations were carried out with the Time Series Processor Package at Warwick University's Burroughs Computer. (For details of the procedure, see the full paper of the same title presented at the PSDE conference.)

The capital variable in the profit function is the total value of capital stock measured in terms of the value of all machinery owned by a firm net of depreciation. The annual wage bill, raw material costs and interest on capital are subtracted from 
the total value of output of a firm to obtain its gross profits. The total value of output is obtained on multiplying output by price per unit taking into account differences in product dimensions. We have divided capital into two components: 'traditional' machine value and 'sophisticated' machine value. 'Traditional' machine value represents the value of machinery which the respondents defined as consisting of lathes up to 8 feet, drills, grinders, welding plants, spraying machines and small furnaces. Large furnaces, lathes larger than 8 feet, power cutting units, honing and milling machines and power presses represent 'sophisticated' technology in the trade. Most of these machines are imported and enable standardization of parts to undertake assembly-line production. The value of such machines, net of depreciation, is summed up to define our variable, 'sophisticated' machine value.

The labour variable is also divided into two components: skilled and unskilled. Skilled workers include turners, welders, fitters, shapermen, foremen and painters. Helpers, apprentices and unskilled workers constitute unskilled workers.

Years of schooling measures the years spent by the entrepreneur to acquire the highest level of education.

In addition to these five variables, we have four town dummies, one each for Daska, Multan, Faisalabad, Sialkot/Gujranwala and Lahore to capture the impact of location on firm's efficiency. The fifth is the biradari dummy which enables us to quantify the influence of entrepreneurs belonging to the lohar biradari. Finally, the firm-experience dummy captures the impact of entrepreneurs having more than eight years' experience of the industry.

The results of likelihood ratio tests on restrictions on the profit functions for the four groups of firms indicate that firms maximize profits and experience constant returns to scale. The estimated variable coefficients in the profit functions, reported in the Appendix Table, incorporate these two restrictions. Indirect estimates of production elasticities and marginal products are reported in Table 2. (For the complete discussion, see the PSDE conference paper.)

Our findings are that within small and large firms marginal products of skilled and unskilled workers are quite similar although the values are nearly 50 percent higher for the large firms than for small firms. This explains the higher wages paid by the large firms. A similar relation between marginal products and wages exists between tubewell and non-tubewell firms, probably due to the presence of the greater number of large firms amongst the latter.

Returns to capital are lower for tubewell firms than for non-tubewell firms for both categories of machines. This may reflect the age of the firm since most tubewell firms are considerably older than the non-tubewell firms and thus have old machinery with lower productivity. There is little difference in returns to capital between small and large firms. Regarding differences in efficiency due to the type of machinery in use, we find that when we group firms by product, returns to sophisticated machinery are greater in the tubewell firms than in the non-tubewell firms,
Table 2

Indirect Estimates of Production Elasticities and Marginal Products by Firm Groups

\begin{tabular}{llcccc}
\hline \multirow{2}{*}{ Variable } & Marginal & \multicolumn{4}{c}{ Production Elasticities } \\
\cline { 3 - 6 } & Product & $\begin{array}{c}\text { Tubewell } \\
\text { firms }\end{array}$ & $\begin{array}{c}\text { Non-tubewell } \\
\text { firms }\end{array}$ & $\begin{array}{c}\text { Small } \\
\text { firms }\end{array}$ & $\begin{array}{c}\text { Large } \\
\text { firms }\end{array}$ \\
\hline Skilled workers & Rs./month & 0.194 & 0.137 & 0.142 & 0.129 \\
& & 705 & 952 & 737 & 1107 \\
Unskilled workers & Rs./month & 0.095 & 0.168 & 0.108 & 0.171 \\
& & 754 & 1154 & 767 & 1154 \\
'Sophisticated' & Rs./Rs. & 0.239 & 0.236 & 0.218 & 0.207 \\
machinery & & 2.89 & 3.29 & 3.66 & 3.06 \\
'Traditional' & Rs./Rs. & 0.472 & 0.458 & 0.532 & 0.566 \\
machinery & & 1.41 & 3.47 & 3.47 & 4.14 \\
\hline
\end{tabular}

probably because of the presence of a large number of small firms amongst the former who have less access to the 'sophisticated' machinery. This is confirmed further by comparing firms according to size; compared with the large firms, the smaller firms, on average, have higher returns on 'sophisticated' machinery than on the 'traditional' machinery.

Regarding schooling, we find that our measure, the number of years of the entrepreneur's education, is positively correlated with efficiency and is significan (at the 10-percent level of significance), only for tubewell-manufacturing firms. Other specifications (linear, parabolic and dummies capturing various education levels) did not perform any better. We also tried dummies for levels of technica education but these also were insignificant, perhaps because there were not enough observations: only six entrepreneurs in our sample reported having received any technical education at all.

Entrepreneur's experience is significant and positively correlated with firm's efficiency for all four groups of firms. The specification that yields the best results is a dummy using eight years of experience as the cut-off point. We also tried the usual inverse U-shaped specification, but it was significant only for the non-tubewel firms. Our results indicate that the entrepreneur's experience is more importan than formal schooling in determining efficiency and thus supports the skepticism with which formal schooling is held by our respondents. This is unfortunate since this attitude is extended to technical education as well. It is not obvious, however, that technical education does not increase efficiency through improvements in product design. 
Our third variable concerning entrepreneural background captures the influence of biradari on efficiency. Here we find that belonging to the lohar biradari improves efficiency significantly amongst the large firms. Given the widespread impression in the industry regarding the skill advantage of the lohar biradari and given also that this biradari is to be found in all categories of firms that we have studied, we expected the biradari dummy to be significant in all four cases. An explanation for why that is not the case may be that the impression that the lohar biradari is very efficient is probably based on the success stories of the few amongst them who did succeed. The successful ones are probably those who entered the industry in its early phases and have adapted to the changing requirements of the market and, in the process, have increased their share of the market. Thus, the efficient large firms are run by entrepreneurs who are the most successful amongst the lohar biradari entrepreneurs.

Regarding location, we find that for tubewell firms, location in Lahore is an advantage over one in Daska because of access to a large casting and forging industry and the market for raw material. There may also be external economies due to the presence of a large number of other tubewell-manufacturing firms. Amongst the non-tubewell firms, firms based in Faisalabad are more efficient than others. This may be explained in terms of the 'Samundri Road' phenomenon. A large section of the light engineering industry in Faisalabad, a booming industrial city, is concentrated along a three-mile section of the Samundri Road at the outskirts of the city. This enables the agricultural machinery manufacturing industry located in this city to effectively take advantages of complementarities with other firms more than it enables the firms located in other towns. The committee system of raising working capital is also more widespread here, which helps in lowering per unit costs. Our results indicate further that large firms are at a greater disadvantage compared with the small firms in Daska and in Multan. Finally, both large and small firms in Faisalabad are technically more efficient than those in Mian Channun. The last result is particularly striking in view of the rapid expansion of the industry in Mian Channun. An explanation may be that the agricultural machinery manufactured in Mian Channun caters for the need of the fast-growing agricultural sector of Multan and Sahiwal districts. This locational advantage results in high demand even though firms located in the more distant Faisalabad can manufacture the machinery at lower per unit costs.

\section{CONCLUDING REMARKS}

\section{Summary of Findings}

Our study shows that most firms in the agricultural machinery industry employ 10 workers or less and invest roughly Rs. 10,000 per worker in the machinery. Most of the machinery used in the production process is domestically produced and performs satisfactorily. This demand for domestically manufactured machinery and raw material, pig iron, manufactured by Pakistan Steel Mill, is an important example of backward linkages of the light engineering sector with the domestic economy. The industry faces imperfect labour and capital markets. Segmentation in the labour market is caused by workers' professional caste, years of experience, size of the firm, and the firm's location. The industry contributes importantly to the pool of skilled workers in the country and this represents another important linkage with the domestic economy. Innovative arrangements in the capital market, such as the 'committee' system, are used for mobilizing capital, generated in trading and by migrants' remittances, which would otherwise be diverted to wasteful consumption. On the question of firm size, we find that being small is important in that it gives a start in the industry through product or area specialization. Once the firm is established, there is little advantage in firms remaining small. We find that both small and large firms are allocatively efficient [5]. Features that contribute to the technical efficiency of firms are entrepreneurs' education, his biradari, and the number of years spent in the industry (the cut-off point being eight years). We find that firms located in towns, such as Lahore and Faisalabad, having concentrations of other industries in the light engineering sector, enjoy complementarities and perform better than other firms. Location in towns like Mian Channun and Daska is important in that it enables firms to cater for specialized markets and thus enjoy high profits.

\section{Policy Considerations}

The main advantage of the light engineering sector lies in the links which it forges with the rest of the economy and in the opportunities it provides to the small entrepreneur to identify sources of demand and thus helps to expand markets. Policies should be formulated to promote these aspects of the sector. In this regard, important policy recommendations are as follows:

(i) Improvements must be effected in the performance of upstream industries - in this instance, Pakistan Steel Mill and the Machine Tool Industry - so that cheap raw materials, such as pig iron, and efficient machining equipment, such as lathes, power presses, shapers, etc., become available to the industry. A policy that inflates the price of domestically available pig iron to subsidize the Steel Mill is highly injurious to the industry.

(ii) The working of capital markets can be improved by increased and easy availability of credit through official channels. The objective here should not be to provide subsidized capital but to relax the constraints that stop the flow of capital to this sector. An important step would be to open up 
more branches of specialized credit institutions in areas where light engineering firms are located and to closely supervise the loaning activities of the commercial banks which act as intermediaries between the specialized institutions and the firms. In this regard, proper project evaluation procedures should be adopted to make firms' profitability an important criterion in loaning decisions instead of firm size and other entrepreneurial features as is currently the practice.

(iii) An important policy for removing factors that segment the labour market and thus impede its working is to increase the size of the market. An effective way to do this is to provide more commuting facilities to attract more workers into towns that are important centres of the industry. Further, to increase the pool of skilled labour, apprenticeship schemes should be started in private firms rather than in specially created training centres which are held in low regard in the industry.

(iv) Many studies, including ours, have pointed out that certain towns, such as Mian Channun, Daska, and Faisalabad, have greater advantage than other towns as growth centres for these industries. A careful study of the features of these towns, such as the depth of entrepreneurial talent, workers' skills, access to raw materials and markets for the products, needs to be made to determine whether similar features can be replicated elsewhere. Further, transport and communication facilities, such as the provision of telephone exchanges and improving the workings of railways, will help the industry to grow.

(v) The Government must take stock of the research and development activities of the industry and subsidize a few carefully chosen firms to further promote this important activity. This policy (as the experience of the Agricultural Machinery Division in Pakistan shows) is more likely to encourage innovations than one which restricts research and development to specially created Government institutions.

(vi) Finally, policies should be pursued that ensure continued and expanding demand for the products of the light engineering sector. In the case of agricultural machinery industry, this amounts to abandoning policies that encourage large-scale farming with imported high-technology machinery.
Table I

Estimated Coefficient for Profit Functions with Constant Return to Scale and Profit Maximization Restrictions

\begin{tabular}{|c|c|c|c|c|}
\hline & Tubewell Firms & Non-tubewell Firms & Small Firms & Large Firms \\
\hline Constant & $\begin{array}{l}4.590 * \\
(3.380)\end{array}$ & $\begin{array}{c}3.778^{*} \\
(3.934)\end{array}$ & $\begin{array}{c}4.417 * \\
(4.269)\end{array}$ & $\begin{array}{c}6.612 \\
(5.559)^{*}\end{array}$ \\
\hline $\begin{array}{l}\text { log of skilled } \\
\text { worker's wages }\end{array}$ & $\begin{array}{c}-0.273^{*} \\
(-9.618)\end{array}$ & $\begin{array}{c}-0.200 * \\
(1.819)\end{array}$ & $\begin{array}{c}-0.189 * \\
(2.225)\end{array}$ & $\begin{array}{c}-0.184 * \\
(3.517)\end{array}$ \\
\hline $\begin{array}{l}\text { log of unskilled } \\
\text { worker's wages }\end{array}$ & $\begin{array}{l}-0.134 \\
(-1.035)\end{array}$ & $\begin{array}{c}-0.240 \\
(-1.785)\end{array}$ & $\begin{array}{l}-0.144 * \\
(-2.211)\end{array}$ & $\begin{array}{l}-0.244 * \\
(-3.155)\end{array}$ \\
\hline $\begin{array}{l}\text { log of value of } \\
\text { 'traditional' } \\
\text { machines }\end{array}$ & $\begin{array}{c}0.336 * \\
(3.790)\end{array}$ & $\begin{array}{c}0.337 * \\
(6.536)\end{array}$ & $\begin{array}{c}0.291^{*} \\
(5.647)\end{array}$ & $\begin{array}{c}0.296^{*} \\
(4.788)\end{array}$ \\
\hline $\begin{array}{l}\log \text { of value of } \\
\text { 'sophisticated' } \\
\text { machines }\end{array}$ & $\begin{array}{c}0.664^{*} \\
(3.101)\end{array}$ & $\begin{array}{c}0.663 * \\
(3.875)\end{array}$ & $\begin{array}{c}0.709 * \\
(3.783)\end{array}$ & $\begin{array}{c}0.704 * \\
(4.300)\end{array}$ \\
\hline $\begin{array}{l}\log \text { of years } \\
\text { of education }\end{array}$ & $\begin{array}{l}0.003^{* *} \\
(1.594)\end{array}$ & $\begin{array}{c}0.002 \\
(0.912)\end{array}$ & $\begin{array}{c}0.0004 \\
(0.468)\end{array}$ & $\begin{array}{l}-0.001 \\
(-0.255)\end{array}$ \\
\hline Daska dummy & - & $\begin{array}{c}0.188 \\
(0.421)\end{array}$ & $\begin{array}{l}-0.526 \\
(-1.277)\end{array}$ & $\begin{array}{l}-0.823 * \\
(-2.148)\end{array}$ \\
\hline $\begin{array}{l}\text { Faisalabad } \\
\text { dummy }\end{array}$ & - & $\begin{array}{c}0.331 \\
(1.081)\end{array}$ & $\begin{array}{c}1.65^{*} \\
(2.261)\end{array}$ & $\begin{array}{c}0.821 * \\
(3.036)\end{array}$ \\
\hline Multan dummy & - & $\begin{array}{l}-0.076 \\
(-0.232)\end{array}$ & $\begin{array}{c}0.101 \\
(0.248)\end{array}$ & $\begin{array}{l}-0.916^{*} \\
(-1.854)\end{array}$ \\
\hline $\begin{array}{l}\text { Sialkot/ } \\
\text { Gujranwala dummy }\end{array}$ & - & $\begin{array}{c}0.226 \\
(0.643)\end{array}$ & $\begin{array}{c}0.266 \\
(0.634)\end{array}$ & $\begin{array}{c}0.296 \\
(0.291)\end{array}$ \\
\hline Lahore dummy & $\begin{array}{c}0.716^{*} \\
(1.780)\end{array}$ & $\begin{array}{l}0.780^{* *} \\
(1.533)\end{array}$ & $\begin{array}{c}0.505 \\
(1.087)\end{array}$ & $\begin{array}{l}-0.41 \\
(-0.897)\end{array}$ \\
\hline $\begin{array}{l}\text { Entrepreneur's } \\
\text { experience } \\
\text { ( } 8 \text { years) dummy }\end{array}$ & $\begin{array}{c}0.625 \\
(1.395)\end{array}$ & $\begin{array}{c}0.544 * \\
(2.204)\end{array}$ & $\begin{array}{c}0.611^{*} \\
(4.341)\end{array}$ & $\begin{array}{c}0.735^{*} \\
(3.194)\end{array}$ \\
\hline Biradari dummy & $\begin{array}{l}-0.065 \\
(-0.176)\end{array}$ & $\begin{array}{c}0.169 \\
(0.789)\end{array}$ & $\begin{array}{l}-0.139 \\
(-0.559)\end{array}$ & $\begin{array}{c}0.321^{*} \\
(1.666)\end{array}$ \\
\hline $\begin{array}{l}\log \text { of likelihood } \\
\text { function }\end{array}$ & 59.954 & 142.670 & 112.767 & 72.61 \\
\hline
\end{tabular}

*indicates significance at the 5-percent level. $* *$ indicates significance at the 10 -percent level. 


\section{REFERENCES}

1. Anderson, D. "Small Industry in Developing Countries. A Discussion of Issues". World Development. Vol. 10, No. 11. 1982.

2. Baumol, W. J. "Entrepreneurship in Economic Theory". American Economic Review (Papers and Proceedings). Vol. LVIII, No. 2. May 1968.

3. Child, C. F., and H. Kaneda. "Links to the Green Revolution: A Study of Small Scale Agricultural Related Industry in the Pakistan Punjab". Economic Development and Cultural Change. January 1975.

4. Field, G. S. Poverty, Inequality and Development. Cambridge (UK): Cambridge University Press. 1980.

5. Hamid, N., and I. Nabi. "Role of Small Scale Industry in Employment Generation: Some Basic Issues". 1984. (Mimeographed; prepared for ARTEP/ILO, Bangkok)

6. Hirschman, A. D. The Strategy of Economic Development. New Haven, Con necticut: Yale University Press. 1966.

7. Kaldor, N., and J. Robinson (eds.). Industrialization in Developing Countries. Cambridge (UK): Cambridge Overseas Study Committee. 1965.

8. Lau, L., and P. A. Yotopoulos. "Profit, Supply and Factor Demand Functions". American Journal of Agricultural Economics. Vol. 54. 1972.

9. Marsden, K. "Progressive Technologies for Developing Countries". In W. Galenson (ed.), Essays on Employment. Geneva: ILO. 1971.

10. Morawetz, D. "Employment Implications of Industrialization in Developing Countries: A Survey". Economic Journal. September 1974.

11. Nabi, I. "The Economics of Agricultural Machinery Industry in Developing Countries". Ottawa: IDRC. (Forthcoming, 1984)

12. Nabi, I. "Investment Decisions in Imperfect Capital Markets". Ottawa: IDRC (Forthcoming, 1984)

13. Pakistan Agricultural Research Council. Agricultural Machinery Division. "A Handbook of Agricultural Machinery Manufacturers in Pakistan”. Islamabad. n.d. (Mimeographed)

14. Pakistan Agricultural Research Council. Agricultural Machinery Division. "A Review of Mechanized Harvesting in Pakistan”. Islamabad. 1981. (Mimeographed)

15. Papanek, G. "The Development of Entrepreneurship". American Economic Association; Papers and Proceedings. Vol. 52. May 1967.

16. Punjab. Directorate of Industries and Mineral Development. "A Survey of Agricultural Implements Industry in Punjab (1978-79)”. Lahore.

17. Rafe-uz-Zaman (ed.) Pakistan Year-Book 1970. Karachi: National Publish ing House. 1970.
18. Schumacher, E. F. Small is Beautiful. New York: Harper and Row. 1973.

19. Sen, A. K. Choice of Techniques. London: Basil Blackwell. 1968.

20. Staley, E., and R. Morse. Modern Small Scale Industry for Developing Countries. New York: McGraw-Hill. 1965.

21. Stewart, F. Technology and Underdevelopment. London: Westview. 1977.

22. White, L. J. "The Evidence on Appropriate Factor Proportions for Manufacturing in Less Developed Countries: A Survey". Economic Development and Cultural Change. Vol. 27, No. 1. October 1978.

23. Yotopoulos, P. A. Equilibrium of the Household: An Application with Demographic Decision Making. Stanford, Calif.: Stanford University. 1982. (Working Paper No. 8202 of the Food Research Institute)

24. Zellner, A. "An Efficient Method of Estimating Seemingly Unrelated Regressions and Tests for Aggregation Bias". Journal of the American Statistical Association. Vol. 57. 1962. 


\section{Comments* on \\ "Issues in the Economics of Industrialization in Developing Countries: A Case Study from Pakistan's Light Engineering Sector"}

First of all, I should like to thank Professor Naqvi for having invited me to this Conference. It is a privilege and an honour for me. It is also a refreshing change from my official preoccupations.

Because I know Mr. Ijaz Nabi so well, I have not made an elaborate statement on how impressed I am with his scholarship and how much I enjoyed reading his paper. So I shall get right down to my comments.

In the beginning of the paper, Mr. Nabi sets out the arguments on the sizeefficiency debate and discusses the advantages of the small-scale sector. I wonder whether, in all this discussion, he has not perhaps missed a really essential part of the argument in favour of the small-scale sector. There has never really been any disputing the fact that the small-scale sector has a lower capital-labour ratio and a higher employment coefficient per unit of output and capital. But the most striking thing about the small-scale sector is that it is an extremely efficient user of capital; that is, it has a low capital-output ratio when compared with the large-scale sector. The classic piece of work on this was done by Ranis some thirty years ago and there have been other studies done by the World Bank and Asian Development Bank to help them in formulating lending policies for small-scale industries in various countries, including Pakistan. The difference between the two sectors in respect of the efficiency with which capital is used is quite marked. In the large-scale sector, the capital-output ratio is of the order of about 2:1 and in the small-scale sector only about half as much. So, I would say that this is essentially the main argument in favour of small enterprises: they are extremely efficient users of a scarce resource.

The argument in the large-scale sector is that as you move up the scale curve, the proportion of capital to labour rises quite sharply. And although this rise in the capital-labour ratio is reflected in a corresponding increase in the productivity of

*These comments are based on the paper presented in the Conference and not on the revised version of the paper. 
labour, there does occur some retardation in the productivity of capital. This is the standard neoclassical result in a world of linear homogeneous production functions with constant returns to scale. So, the large-scale sector generally has a higher capital-output ratio; it is a comparatively less efficient user of capital.

The second point Mr. Nabi mentions is that one of the advantages of the large-scale sector is that it generates a larger investible surplus. This, I would submit, is a highly contentious statement. For there is no evidence, in the case of Pakistan at least, to support the argument that the large-scale sector has generated a larger reinvestible surplus or, as Galenson and Leibenstein call it, a higher re-investment coefficient. On the contrary, according to Ranis, it is in the small- and medium-sized firms that the proportion of internally generated profits, which are reinvested, is maximized, as a proportion of both output and investment. This is possibly explained by the much greater competitive pressures on them and, as Mr. Nabi suggests in the paper, by less access to institutional sources of credit.

I would have liked to see much more discussion on his sample but I note that Mr. Nabi has described this in some considerable detail elsewhere.

I am not quite clear on what Mr. Nabi's cut-off point is for large firms in his sample. Is he looking at large and small firms within the small scale sector, or is he considering large and small firms per se? In either event, his technical ratios, as derived from his sample, surprised me. If one looks at the CMI for 1980-81 and in particular at the agricultural machinery sub-sector, the average productivity of capital (the output-capital ratio) is reported to be 2.3. This is, in fact, higher than the average productivity in the sample of small firms, quite the reverse of what we are told about the relative efficiency of cpaital use in the two size categories and about which I have spoken earlier. I am a little perplexed by all this.

Just as a matter of interest, the average capital-labour ratio in the large-scale sector is about three times as high as that observed in the small-scale sector, with the differences in the productivity of labour being about two-and-a-half times as much. This is reasonable, given the much higher capital intensity of the production techniques applied.

Turning to Mr. Nabi's econometric specification and his results, I am afraid I don't know much about likelihood functions and all the rest, so that my questions are of a rather primitive kind. He starts with a simple Cobb-Douglas on the assumption that this is an appropriate specification to use. There are no tests for the elasticity of substitution which may have suggested an alternative specification. He uses a profit function whereas I would have preferred, given the sort of data one has to work with, a simple Cobb-Douglas approach, divided everything by employment, and taken output per man as my dependent variable. What I am trying to get at is what additional insights does this more complicated specification and estimation afford?
Amongst my other rather primitive questions: There is no $R^{2}$. Now, I am sure that given the very fancy technique that $\mathrm{Mr}$. Nabi is using, it is terribly unfashionable for me to suggest such a thing. But I like to come back to basic and fundamental issues. For example, he has 120 firms in his sample and my experience with working with firm-level data is that while the overall results can be good, you get terrible $R^{2}$ 's because of the large random variations in the data. There is also no oldfashioned discussion of multicollinearity and things like that. I suspect that Mr. Nabi's capital variables are highly collinear; that his employment variables are also highly collinear. There are also some excluded variables: the rate of growth of demand; capital utilization rates; the age of the capital stock; and market oriention, that is whether these firms sell their outputs in the domestic market or in the external market, or in both. Excluded variables can, as we know, lead to biased results.

Finally, I have always had the feeling that perhaps this small-scale industry bit has been over-romanticized. I am not suggesting that the small-scale sector in Pakistan has not been a good thing and has not performed well. It has been good for Pakistan, for growth and employment generation, for equity and for exports. But having said that, I think it is important to remember, indeed to underscore, that despite being a large and dynamic sector, it is extremely primitive and technologically backward. A great deal, therefore, needs to be done to raise the technical dynamism of this sector, or, as Kaldor would say, to raise the height (and perhaps change the shape) of the technical progress function.

Chief,

Meekal Aziz Ahmed

International Economic Section,

Planning Commission,

Islamabad 